Article

\title{
Energy and Exergy Analyses of a Solid Oxide Fuel Cell-Gas Turbine-Organic Rankine Cycle Power Plant with Liquefied Natural Gas as Heat Sink
}

Mohammad H. Ahmadi ${ }^{1, *}$, Mirhadi S. Sadaghiani ${ }^{2}$, Fathollah Pourfayaz ${ }^{2}$, Mahyar Ghazvini ${ }^{2}$, Omid Mahian ${ }^{3,4}$, Mehdi Mehrpooya ${ }^{2,5}$ and Somchai Wongwises ${ }^{3, *}$

1 Faculty of Mechanical Engineering, Shahrood University of Technology, Shahrood 3619995161, Iran

2 Renewable Energies and Environment Department, Faculty of New Sciences and Technologies, University of Tehran, Tehran 1417466191, Iran; hadisadaghiani@yahoo.com (M.S.S.); pourfayaz@ut.ac.ir (F.P.); xillumator@yahoo.com (M.G.); mehrpoya@ut.ac.ir (M.M.)

3 Fluid Mechanics, Thermal Engineering and Multiphase Flow Research Lab. (FUTURE), Department of Mechanical Engineering, Faculty of Engineering, King Mongkut's University of Technology Thonburi, Bangmod, Bangkok 10140, Thailand; omid.mahian@gmail.com

4 School of Aeronautic Science and Engineering, Beihang University, Beijing 100191, China

5 Hydrogen and Fuel Cell Laboratory, Faculty of New Sciences and Technologies, University of Tehran, Tehran 14176-14418, Iran

* Correspondence: mohammadhosein.ahmadi@gmail.com or mhosein.ahmadi@shahroodut.ac.ir (M.H.A.); somchai.won@kmutt.ac.th (S.W.)

Received: 20 March 2018; Accepted: 5 June 2018; Published: 22 June 2018

\begin{abstract}
An exergy analysis of a novel integrated power system is represented in this study. A Solid Oxide Fuel Cell (SOFC), which has been assisted with a Gas Turbine (GT) and Organic Rankine Cycle (ORC) by employing liquefied natural gas (LNG) as a heat sink in a combined power system is simulated and investigated. Initially in this paper, the integrated power system and the primary concepts of the simulation are described. Subsequently, results of the simulation, exergy analysis, and composite curves of heat exchangers are represented and discussed. The equations of the exergy efficiency and destruction for the main cycle's units such as compressors, expanders, pumps, evaporators, condensers, reformers, and reactors are presented. According to the results, the highest exergy destruction is contributed to the SOFC reactor, despite its acceptable exergy efficiency which is equal to $75.7 \%$. Moreover, the exergy efficiencies of the ORC cycle and the whole plant are determined to be $64.9 \%$ and $39.9 \%$, respectively. It is worth noting that the rational efficiency of the integrated power system is $53.5 \%$. Among all units, the exergy efficiency of the LNG pump is determined to be $11.7 \%$ the lowest exergy efficiency among the other investigated components, indicating a great potential for improvements.
\end{abstract}

Keywords: organic Rankine cycle; LNG; solid oxide fuel cell; exergy efficiency; exergy destruction

\section{Introduction}

Owing to the global environmental concerns and energy crisis, applications of renewable energy, for instance, wind/solar energy, merit high attention [1-3]. Whereas the artificial refrigerants show significantly high define (GWP) and define (ODP), recently the environmentally friendly ecological refrigerant carbon dioxide $\left(\mathrm{CO}_{2}\right)$ has achieved significant attention and has been recognized as an appropriate substitute refrigerant due to its outstanding heat transfer features, and its non-toxicity and non-flammability [4,5]. Therefore, machinery systems employing $\mathrm{CO}_{2}$ as working fluid to transform absorbed heat into thermal, mechanical energy and hereafter electricity probably 
represent the greatest advances among other current prospects. Medium heat transfer fluids are extensively utilized in various energy systems for transferring heat between sub-systems. Nowadays, several scholars have concentrated on refining the performances of the solar system, particularly solar collectors' effect, and other elements on the thermal cycle performances. For instance, variables affecting the operation of water-in-glass collector tubes have been examined by Morrison and Budihardjo. Additionally, the performance of a water-in-glass evacuated tube solar heater has been studied. Riffat and Zhao [6,7] studied the heat transfer and thermodynamic features of a hybrid heat pipe solar collector/CHP system employing $n$-pentane as working fluid and the system worked on a representative Rankine cycle.

Additionally, working fluids properties affect the thermodynamic performance of cycles. Applying appropriate working fluid in a cycle can lead to higher efficiency or output power. One of the methods which are applicable is utilizing transcritical cycles to achieve better performance [8]. Several studies have focused on transcritical cycles operating with $\mathrm{CO}_{2}$ as working fluid. An analysis of the transcritical $\mathrm{CO}_{2}$ refrigeration cycle associated with the second law has been demonstrated by Fartaj et al. [9]. Yang et al. [10] carried out an exergy analysis on the transcritical $\mathrm{CO}_{2}$ refrigeration cycle working with an expander. Chen et al. [9] and Cayer et al. [11] implemented a comprehensive investigation of the $\mathrm{CO}_{2}$ Rankine cycle. These types of research focused on analyzing the system variables on a particular condition. There are limited investigations concentrating on the system performance with respect to time, not to declare the $\mathrm{CO}_{2}$ Rankine cycle exergy analysis with time.

Furthermore, global warming and air pollution which lead to environmental issues are growing due to industries development and daily rise in energy demand. Natural gas (NG) has been known as an eco-friendly type of energy source which could be widely utilized in the combustion process [12]. Consequently, using NG as an alternative resource for the sake of meeting the growing energy demand and reducing the environmental pollution is considered as a proper approach. Liquefied natural gas (LNG) is natural gas which has been converted into a liquid form in order to be transportable for long distances with lower difficulty [13]. Moreover, through the liquefying procedure, LNG can deliver a great amount of cryogenic energy, due to its temperature which is very low $(110 \mathrm{~K})$. The cryogenic energy can be extracted during the process of regasification. In other words, LNG can be used as an alternative energy supply. Nonetheless, the conventional regasification methods waste the cold energy and still need a great amount of energy supply [14-18]. Hence, investigation and development of cold recovery processes, has been the aim of many studies in the LNG regasification process. One of the most reliable methods for electricity power production is cold recovery process of LNG. About 16 cryogenic power plants using the recovered cryogenic energy of LNG have been built in Japan since 1979 to 2000 [19]. Efficiencies and performances of aforementioned cryogenic power plants have been continually enhanced. Dispenza [20,21] presented a modified process in a combined heat and power (CHP) system, which utilized LNG stream through the regasification stage, as a cold source. Szargut [22] evaluated the performance of three different cryogenic power plants.

Several studies have focused on improving the performance of LNG cold energy recovery, by combining conventional power cycles or by advance optimization of the main variables of the cycles. Choi [23] presented a cascade Rankine cycle in order to recover LNG cold energy. The results showed that by increasing the stage numbers, exergy and energy efficiencies and total power output would enhance ( $<3$ stages). Gomez [24] designed a new closed Brayton cycle power plant which includes a steam Rankine cycle, in which the regasification of LNG provided the available cold exergy. Still Gomez [14], evaluated the traditional thermodynamic cycles in order to enhance the power plant performance by using the cryogenic energy of LNG and provided a selection criterion for the working fluids. Dong [25] studied and modified a model, which used the LNG cryogenic energy to generate power by Stirling cycle.

The properties of working fluids and operational conditions, directly affect the power generation efficiency. Accordingly, some researchers studied the working fluid properties to enhance [26] the recovered cold energy of LNG. $\mathrm{CO}_{2}$ is a proper choice for power generation systems by employing 
LNG cold energy $[27,28]$. It is shown that low-temperature natural gas can be employed as a heat sink to condense the $\mathrm{CO}_{2}$. Additionally, employing $\mathrm{CO}_{2}$ can be considered as a solution for some environmental issues including rising sea levels and global warming. Some researchers have investigated capturing $\mathrm{CO}_{2}$ over cold energy recovery in LNG-fueled power plants. Liu [29] performed a thermo-economic analysis on a zero- $\mathrm{CO}_{2}$ emission and refrigeration cogeneration cycle. Zhang [30] studied a new configuration of the LNG-fueled power plant that liquefies the $\mathrm{CO}_{2}$ after combustion stage, and captures it without additional energy use. Alabdulkarem [31] studied an LNG plant with $\mathrm{CO}_{2}$ capture and sequestration in order to decrease the energy use through the $\mathrm{CO}_{2}$ liquefaction process. These investigations were subjected to 'self-capturing' which is related to the post-capture system. Nonetheless, some industries such as magnetite processing generate large amounts of $\mathrm{CO}_{2}$ without combustion.

One of the promising approaches with low emission and high efficiency in comparison with fossil fuel-based systems is Solid oxide fuel cell (SOFC) [32]. SOFC typically performs at a high temperature, approximately $600-1000{ }^{\circ} \mathrm{C}$ [33]. This technology has the ability to be integrated with other classical and regular thermodynamic cycles for enhancing the energy conversion efficiency. SOFC-GT system is a general approach to recover the waste heat from the SOFC. This system is provided by integrating a SOFC and a gas turbine (GT) as the bottoming cycle to improve the total efficiency via recovering waste heat from SOFC output. The theoretical backgrounds and conceptual models of the hybrid SOFC-GT system were studied and analyzed by various scholars for decades [34-47].

Solid oxide fuel cells have the ability to be coupled with bottoming power cycles, including Brayton [48], Rankine [49], Kalina [50] and Stirling [51] cycles, tri-generation systems [52], and renewable energy systems [53], to reach efficient power generation up to $80 \%$ efficiency [54,55].

Integrating SOFCs with high output temperatures (i.e., up to $1000^{\circ} \mathrm{C}$ ), with a bottoming steam Rankine cycle (SRC) [56-58] or organic Rankine cycle (ORC) [59-64], might limit SOFC operation temperature, and/or increase Rankine working fluid critical temperature. In spite of reported energy efficiencies of up to 71\% [57], studies of SOFC-SRCs are limited. A single pressure level superheated SRC with hybrid SOFC-SRC thermal efficiencies of $62-68 \%$ has been used by Rokhi, depending cycle structure and operating conditions [63,64]. Gandiglio et al. [49] reported thermal efficiency of $65 \%$ by employing a three-pressure level SRC for recovering the waste heat of SOFC. Mehrpooya et al. [58] coupled a SOFC with a three-pressure level regenerative SRC at live steam pressures of 60-100 bar in order to reach $62.4 \%$ of electrical efficiency. ORCs have lower operating pressure, more compact layout and simpler structure, enhanced reliability, and reduced maintenance in comparison with SRCs [65].

Generally, SOFC is supplied by the methane as fuel. The methane is supported by the natural gas that is usually accumulated as LNG at $-161^{\circ} \mathrm{C}$ for large scale of manufacturing use. Throughout the natural gas liquefying process, a huge amount of mechanical energy is employed in the refrigeration process. Consequently, LNG comprises considerable cold energy. If the LNG cold energy could be retrieved in the fuel feeding process for SOFC, the efficiency of the suggested SOFC-GT-ORC unified power system could be increased. Various methods of LNG cold energy employing were proposed in previous years [66-70] including material freezing, intake air-cooling, and power generation. Liu and Guo [71] suggested an innovative cryogenic cycle via employing working fluids, comprising a binary mixture and improving the energy retrieval effectiveness of a LNG cold power creation, integrating with a vapor absorption process. The outcomes of simulation revealed that the innovative power cycle with LNG had significantly higher efficiency than the conventional ORC. Song et al. [27] suggested a transcritical $\mathrm{CO}_{2}$ power system powered by solar energy via employing LNG as heat sink. Their study revealed that the entire power cycle efficiency increased by employing the LNG cold energy underneath the particular situation and it can be additionally raised via parametric optimization.

Based on the literature review, several studies have been conducted on integrating various cycles with SOFC; however, there few studies focused on SOFC-GT-ORC. For instance, Eveloy et al. [72] investigated SOFC-GT-ORC systems and observed an enhancement in power generation by integrating 
these systems. Utilizing SOFC-GT-ORC for micro-scale power generation was investigated by Ebrahimi et al. [73]. It was concluded that these types of systems are efficient for power generation. In the present study, in addition to the mentioned configuration, LNG cold energy is utilized in order to achieve higher efficiency. Using LNG as a heat sink in SOFC-GT-ORC system was investigated by Yan et al. [74]; however, exergy analysis was not performed by the authors which is conducted in this study. Exergy analysis enables designers to distinguish the components with high exergy destruction rate and helps them to optimize the system more appropriately. The proposed system can be used for small-scale power generation by heat recovery from SOFCs utilized in industrial activities which consume LNG as fuel. Integrating the components (SOFC, ORC, GT and LNG as a heat sink) will lead to a high efficiency of the overall system.

In the suggested SOFC-GT-ORC unified power system, LNG is employed as a heat sink to cool the compressor inlets, to condense the turbine outlet and lastly supply the fuel for the SOFC. In order to improve the power output of the ORC, LNG can decrease the temperature of condensing to a very low value, owing to considerable decreasing in the back pressure of turbine via the cryogenic condenser. In addition, LNG can turn cold the air in the intercooler between the two compressors that decreases the compressor intake air temperature, results in lower required work for the compression process.

In this paper, an integrated power system is studied by applying exergy and energy analyses as the principal methods. First, the integrated power system is described; afterward, the primary concepts of the simulation are discussed. Subsequently, results of the simulation, exergy analysis, and composite curves of heat exchangers are represented and discussed. In this design investigated of all components by Pinch technology and Exergy analysis. these tools for this design system used the first time.

\section{System Description}

The flow sheet of an integrated power generation system, which uses LNG as a heat sink, is shown in Figure 1. In Figure 1, two compressors are used to compress the air stream to the SOFC stack operating pressure. The outlet air stream of the compressor (air compressor 1) is cooled in the heat exchanger (HX-1) by the low-temperature natural gas stream. Subsequently, after compression by the compressor (air compressor 2), the air stream is heated in the heat exchanger (HX-2) by the outlet stream of the gas turbine. The water stream (13) is pumped to the pre-reformer operating pressure and heated in the heat exchanger (HX-4) by the exhaust of the heat exchanger (HX-3) before entering to the pre-reformer reactor as steam.

On the other hand, the LNG stream after heating in several heat exchangers (HX-5, HX-1, and refrigeration storage) is compressed to the pre-reformer operating pressure. Afterwards, the natural gas stream is heated in the heat exchanger (HX-3) by the outlet stream of the heat exchanger (HX-2) and enters to the pre-reforming reactor. In the pre-reformer reactor, regarding reforming reactions, a fraction of the natural gas is transformed into hydrogen. The product of the pre-reformer reactor (25), which contains the hydrogen heated in the heat exchanger (HX-2), enters to the SOFC stack as stream (26). The air stream, after preheating in the heat exchanger (HX-2) and reaching to an appropriate temperature, enters the SOFC stack, where electrochemical and reforming reactions happen concurrently. The reforming reaction is an endothermic one; therefore, a part of the heat emitted from the electrochemical reactions is consumed by the reforming reaction. A DC current is produced by the electrochemical reaction, which the inverter converts into AC.

The outlet streams of the anode and the cathode of the SOFC, (6) and (5(a)), respectively, enter the afterburner reactor. The untransformed part of the fuel in SOFC reactor burns in the afterburner. The outlet of the afterburner reactor with high pressure and the temperature is expanded by the gas turbine to produce power. As aforementioned, the exhaust of the gas turbine is used to heat up the air, natural gas, and water streams.

HCFC-123 is used as working fluid in the ORC Brayton cycle. The organic working fluid of the ORC cycle as stream (27) is compressed by the pump (ORC pump) after leaving the heat exchanger 
(HX-5) as a saturated liquid. Afterwards, the working fluid as stream 28 is introduced into the heat exchanger (HX-6) where it is heated and converted to the superheated vapor. The high-pressure superheat vapor (29) is expanded to low-pressure vapor by ORC turbine to produce power. The exhaust of the ORC turbine (30) is fed to the heat exchanger (HX-5) and is cooled by liquid natural gas to the saturated liquid.

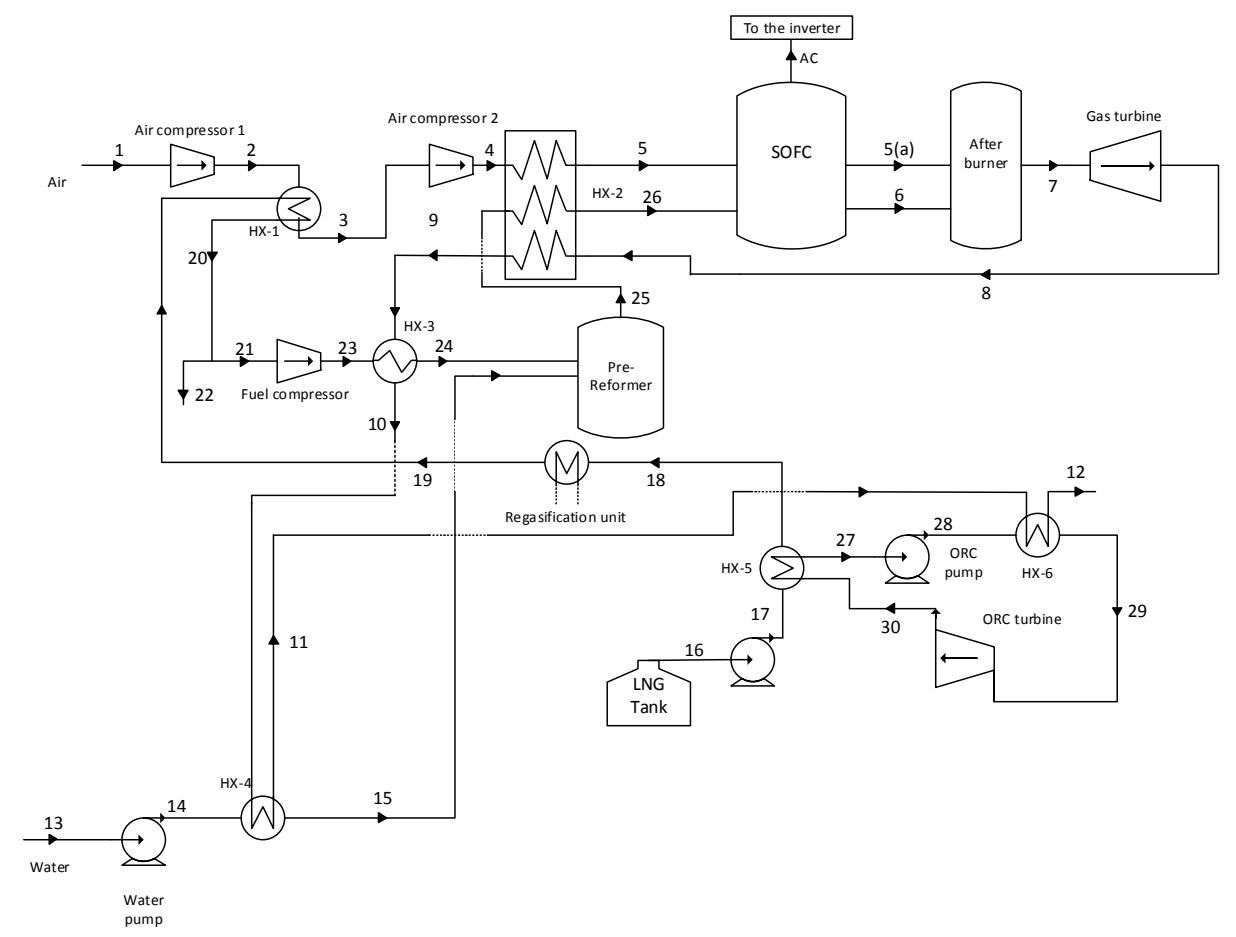

Figure 1. Flowsheet of the integrated power generation system including SOFC-GT-ORC with LNG as heat sink.

HCFC-123 is used as working fluid in the ORC Brayton cycle. The organic working fluid of the ORC cycle as stream (27) is compressed by the pump (ORC pump) after leaving the heat exchanger (HX-5) as a saturated liquid. Afterwards, the working fluid as stream (28) is introduced into the heat exchanger (HX-6) where it is heated and converted to the superheated vapor. The high-pressure superheat vapor (29) is expanded to low-pressure vapor by ORC turbine to produce power. The exhaust of the ORC turbine (30) is fed to the heat exchanger (HX-5) and is cooled by liquid natural gas to the saturated liquid.

\section{Mathematical Model}

\subsection{SOFC Model}

In order to model the system, chemical and thermodynamic relationship between species and components of the system are utilized which are explained for each sub-system. Chemical energy of the fuel is transformed into the electricity in the SOFCs. Oxygen ions are created in the cathode and tracked to the anode via a membrane. Created electrons in the anode move in the cathode after passing over an outer circuit; consequently, electrical current is generated [75]. Electrochemical reactions in the cathode and anode are as below, correspondingly:

$$
\begin{gathered}
2 \mathrm{H}_{2}+2 \mathrm{O}^{2-} \rightarrow 2 \mathrm{H}_{2} \mathrm{O}+4 \mathrm{e}^{-} \\
\mathrm{O}_{2}+4 \mathrm{e}^{-} \rightarrow 2 \mathrm{O}^{2-}
\end{gathered}
$$


Owing to restricted accessibility, the power generation's requisite hydrogen in the fuel cells has to be taking out of the other fuel [76]. At present, fossil fuels including natural gas, coal, and oil are employed for hydrogen production. The supreme cost-effective approach of hydrogen production in large scales is improving the fossil fuels, where the most economical one is natural gas [77]. Relation 3 depicts an endothermic reaction for methane steam improving:

$$
\mathrm{CH}_{4}+\mathrm{H}_{2} \mathrm{O} \rightarrow \mathrm{CO}+3 \mathrm{H}_{2} \quad\left(r_{1}\right)
$$

Additional hydrogen can be generated by the water gas shift reaction that is an exothermic reaction.

$$
\mathrm{CO}+\mathrm{H}_{2} \mathrm{O} \rightarrow \mathrm{CO}_{2}+\mathrm{H}_{2} \quad\left(r_{2}\right)
$$

Relation 5 can present the overall reaction.

$$
\mathrm{CH}_{4}+2 \mathrm{H}_{2} \mathrm{O} \rightarrow \mathrm{CO}_{2}+4 \mathrm{H}_{2} \quad\left(r_{3}\right)
$$

The fuel improvement can be performed inside the SOFC stack. Internal improvement is grouped into two categories: indirect and direct. Indirect contact is performed through a distinct reactor connected to the stack; however, improving and electrochemical reactions happen at the same time interior the SOFC stack on the anode in direct approach [78]. Direct internal improvement has several benefits in comparison with external improvement. To avoid abrupt temperature variations and its coking occurrences, a portion of the fuel improvement (20-30\%) is achieved outside the stack [76].

\subsubsection{Pre-Reformer Reactions Kinetics}

Numerous kinetic models were proposed for WGS and SMR reactions. These kinetic reactions are functions of a type of catalyst and working conditions. WGS and SMR kinetics on an optimized $\mathrm{Ni} / \mathrm{a}-\mathrm{Al}_{2} \mathrm{O}_{3}$ catalyst, within broad ranges of pressure $(120-600 \mathrm{kPa})$ and temperature $(748-823 \mathrm{~K})$ are studied [79]. Developed kinetic reactions are obtained founded on the Freundlich's adsorption model and Langmuir-Hinshelwood-Hougen-Watson (LH-HW) method. LH-HW kinetic rate formulations are used for proposing and model the heterogeneous catalytic reactors. According to this approach, the rate calculating stage is the reaction on the surface of the catalyst [80]. In order to develop the approach, assumptions including plug flow in the reactor, steady state process, insignificant pressure drop, isothermal situations predominate, and no intra-particle and interphase mass transfer restrictions are taken into account [79]. The following expressions formulate the reaction kinetics:

$$
\begin{aligned}
& r_{1}=\frac{5.922 \times 10^{8} \exp \left(\frac{25162}{T}\right)}{P_{H_{2}}^{1.25}} \times\left(\frac{P_{\mathrm{CH}_{4}} \times P_{\mathrm{H}_{2} \mathrm{O}}^{0.5}-\frac{P_{\mathrm{CO}} P_{\mathrm{H}_{2}}^{3}}{1.198 \times 10^{17} \exp \left(-\frac{26830}{T}\right) \times P_{H_{2} \mathrm{O}}^{0.5}}}{(D E N)^{2}}\right) \\
& r_{2}=\frac{6.028 \times 10^{-4} \exp \left(\frac{1852}{T}\right)}{P_{H_{2}}^{0.5}} \times\left(\frac{P_{\mathrm{CO}} \times P_{H_{2} \mathrm{O}}^{0.5}-\frac{P_{\mathrm{CO}} P_{\mathrm{H}_{2}}^{1}}{1.767 \times 10^{-2} \exp \left(\frac{4400}{T}\right) \times P_{H_{2} \mathrm{O}}^{0.5}}}{(D E N)^{2}}\right) \\
& r_{3}=\frac{1.093 \times 10^{3} \exp \left(\frac{13158}{T}\right)}{P_{H_{2}}^{1.75}} \times\left(\frac{P_{\mathrm{CH}_{4}} \times P_{\mathrm{H}_{2} \mathrm{O}}^{1}-\frac{P_{\mathrm{CO}_{2} P_{H_{2}}^{4}}}{2.117 \times 10^{15} \exp \left(-\frac{22430}{T}\right) \times P_{\mathrm{H}_{2} \mathrm{O}}^{1}}}{(D E N)^{2}}\right) \\
& D E N=1+\left(5.127 \times 10^{-13} \exp \left(\frac{13158}{T}\right)\right) P_{C O}+5.68 \times 10^{-10} \exp \left(\frac{11234}{T}\right) P_{H_{2}}^{0.5} \\
& +9.251 \exp \left(\frac{-1912}{T}\right) \frac{P_{\mathrm{H}_{2} \mathrm{O}}}{P_{\mathrm{H}_{2}}}
\end{aligned}
$$


In which $P_{i}(\mathrm{kPa})$ stands for the species $i$ partial pressure and $T(\mathrm{~K})$ represents the temperature of the reactor. The units for $r_{1}, r_{2}$, and $r_{3}$ are $\mathrm{kmol} / \mathrm{s} \cdot \mathrm{kg} \cdot \mathrm{cat}$. Owing to the unit change from $\mathrm{kmol} / \mathrm{s} \cdot \mathrm{kg} \cdot \mathrm{cat}$ to $\mathrm{kmol} / \mathrm{s} \cdot \mathrm{m}^{3}$, the bed density for this reactor is $1780 \mathrm{~kg} \cdot \mathrm{cat} / \mathrm{m}^{3}$.

\subsubsection{Internal and Electrochemical Reforming Reactions Kinetics}

For methane conversion on Ni/YSZ cermet, there are numerous kinetics. They are driven based on the various situations including working circumstance and material composition. The Achenbach and Riensche model is one of the reaction rates that have broadly been employed for modeling objects. This type of kinetic is an Arrhenius kinetic reaction rate:

$$
R_{r}=4274 \times P_{C_{4}} \times \exp \left(\frac{-9863}{T}\right) \times A_{S}
$$

In which, $P_{\mathrm{CH} 4}$ stands for the methane partial pressure in the gas bulk, $A_{s}$ denotes the active surface area to the volume ratio and $T$ represents the mean cell temperature. Steam to carbon ratio, pressure, and temperature range for this kinetic expression are correspondingly $2.6-8,1.1-2.8$ bar and $700-940{ }^{\circ} \mathrm{C}$. Their investigations are based on the anode geometric area with $1.4 \mathrm{~mm}$ anode cermet including $80 \mathrm{wt} \% \mathrm{ZrO}_{2}$ and $20 \mathrm{wt} \% \mathrm{Ni}$. In the anode, WGS Kinetics reaction can be determined based on the Arrhenius approach:

$$
R_{S}=0.0171 \times 10^{10} \times \exp \left(\frac{-12421}{T}\right) \times\left(P_{\mathrm{H}_{2} \mathrm{O}} P_{\mathrm{CO}}-\frac{P_{\mathrm{H}_{2}} P_{\mathrm{CO}_{2}}}{0.019 \exp \left(\frac{4276}{T}\right)}\right)
$$

Electrochemical $\mathrm{H}_{2}$ production rate can be formulated by the following Equation (12):

$$
R_{H_{2}}=\frac{-J}{2 F}
$$

In which $J$ stands for the current density and $F$ represents the Faraday constant. Along with hydrogen, $\mathrm{CO}$ could also be employed as fuel in SOFC, and its oxidation reaction can be presented as follows:

$$
\mathrm{CO}+\mathrm{O}^{2-} \rightarrow \mathrm{CO}_{2}+2 \mathrm{e}^{-}
$$

When both $\mathrm{H}_{2}$ and $\mathrm{CO}$ are available at the same time, $\mathrm{CO}$ has a lower tendency to participate in the electrochemical reactions in comparison with reacting with water [56]. Similarly, the $\mathrm{H}_{2}$ oxidation rate is more than three times higher than the $\mathrm{CO}$ oxidation rate. For the conditions where the WGS reaction is in equilibrium, the Nernst potential created via $\mathrm{H}_{2}$ oxidation equals to $\mathrm{CO}$ oxidation $[57,58]$. Owing to the dominance of $\mathrm{H}_{2}$ oxidation under various circumstances, the influence of the $\mathrm{CO}$ oxidation has been ignored [59-62]. It is deduced that the cell performance is not influenced considerably by CO oxidation $[63,66]$. Outcomes of the experimental data depict that hydrogen oxidation is the principal anodic process in the SOFCs, whereas the shift equilibrium used CO [36].

\subsubsection{SOFC Voltage}

The fuel cell real output voltage is calculated by subtracting the voltage losses from the thermodynamically ideal voltage [37]. The losses in the fuel cells occur due to irreversibilities [81]. In order to determine the output electricity, it is necessary to obtain an actual voltage which leads to more precise efficiency calculation. By applying Equation (14), the actual voltage is calculated in the simulation:

$$
V=E_{\text {thermo }}-\eta_{\text {act }}-\eta_{\text {ohmic }}-\eta_{\text {conc }}
$$

$V$ stands for the actual voltage, $\eta_{\text {act }}$ stands for the activation losses, $E_{\text {thermo }}$ represents the ideal voltage, $\eta_{\text {conc }}$ represents the concentration losses, and $\eta_{\text {ohmic }}$ denotes the Ohmic losses. The bulk 
mole fraction of components and the working temperature of fuel cell affect output ideal voltage. By considering the influential parameters on the output ideal voltage, it can be determined as follows:

$$
\begin{gathered}
E_{\text {thermo }}=1.177-0.06855(t-1)-0.0165(t \ln t-t)-\frac{R T}{n F} \ln \left(\frac{P_{\mathrm{H}_{2} \mathrm{O}}^{0}}{P_{\mathrm{O}_{2}}^{0}{ }_{2} P_{\mathrm{H}_{2}}^{0}}\right) \\
t=\frac{T}{298.15}
\end{gathered}
$$

In which $\mathrm{T}$ stands for the mean cell temperature, and $\mathrm{P}^{0}{ }_{\mathrm{H} 2 \mathrm{O}} ; \mathrm{P}^{0} \mathrm{H}_{2} ; \mathrm{P}^{0} \mathrm{O} 2$ denote the bulk mole fraction of $\mathrm{H}_{2} \mathrm{O}, \mathrm{H}_{2}$ and $\mathrm{O}_{2}$, respectively. As mentioned, it is necessary to subtract the losses from the ideal voltage to obtain the actual output voltage; therefore, each loss is calculated based on the effective factors. First of all, the losses due to electrical resistances are calculated. The resistance of the fuel cell elements (cathode, anode, interconnects and electrolyte) to the ion flow and electrons reduces the performance of the cell which is named Ohmic loss, $\eta_{\text {ohmic }}$ [35]. It can be determined as follows:

$$
\eta_{\text {ohmic }}=j \times \sum_{i}\left(\sigma_{i}\right)^{-1} \times \delta_{i}
$$

$\sigma$ stands for the electronic or ionic conductivity and $\delta_{i}$ represents the cathode, anode, interconnector, and electrolyte thickness. Another influential loss is related to the activation energy required for the electrochemical reactions [82]; this type of loss is related to the mechanism of the reactions which happen across the electrodes and [83]. The rate at which reactants are transformed into the products is restricted due to the required activation energy. Consequently, a portion of the energy is used owing to electrochemical reactions at the cathode and anode. This kind of loss is named activation loss, $\eta_{\text {act }}$ [37]. Various parameters affecting the activation loss must be taken into consideration in determining this loss. The equation below expresses the relation between the activation loss and current density:

$$
j=j_{0}\left[\exp \left(\alpha \frac{n_{e} F}{R T} \eta_{a c t}\right)-\exp \left(-(1-\alpha) \frac{n_{e} F}{R T} \eta_{a c t}\right)\right]
$$

where $n_{e}$ stands for the number of electrons transmitted per electrochemical reaction, $a$ represents the transfer coefficient and $j_{0}$ denotes the exchange current density of the cathode and anode that is determined by the following equations [64]:

$$
\begin{gathered}
j_{0, a n}=\gamma_{a n} \frac{R T}{n_{e} F} \exp \left(-\frac{E_{a c t, a n}}{R T}\right) \\
j_{0, \text { cat }}=\gamma_{c a t} \frac{R T}{n_{e} F} \exp \left(-\frac{E_{a c t, c a t}}{R T}\right)
\end{gathered}
$$

By assuming $a=0.5$ [84], activation loss is determined as follows:

$$
\eta_{a c t}=\frac{2 R T}{n_{e} F} \sinh ^{-1}\left(\frac{j}{2 j_{0, c a t}}\right)+\frac{2 R T}{n_{e} F} \sinh ^{-1}\left(\frac{j}{2 j_{0, a n}}\right)
$$

Another important loss in SOFCs is the concentration loss $\left(\eta_{\text {conc }}\right)$ which is due to concentration gradient at the surface of the electrodes. The porous structure of the electrodes is one of the significant factors which results in the reaction sites have dissimilar concentration compared with the bulk [35]. Concentration losses depend on various factors such as working temperature, bulk and site partial pressure. Concentration loss is determined by the equation below:

$$
\eta_{\text {conc }}=\frac{R T}{n_{e} F} \ln \left(\frac{P_{\mathrm{H}_{2} \mathrm{O}}^{*} P_{\mathrm{H}_{2}}^{0}}{P_{\mathrm{H}_{2} \mathrm{O}}^{0} P_{\mathrm{H}_{2}}^{*}}\right)+\frac{R T}{2 n_{e} F} \ln \left(\frac{P_{\mathrm{O}_{2}}^{0}}{P_{\mathrm{O}_{2}}^{*}}\right)
$$


where, $P_{o i}$ and $P_{i}$ represent reaction bulk and sites partial pressure of the species, correspondingly. $P_{i}$ is calculated as follows:

$$
\begin{aligned}
P_{\mathrm{H}_{2}}^{*} & =P_{\mathrm{H}_{2}}^{0}-\frac{j \times \delta_{a n} \times R \times T}{n_{e} F D_{\mathrm{H}_{2}}^{e f f}} \\
P_{\mathrm{H}_{2} \mathrm{O}}^{*} & =P_{\mathrm{H}_{2} \mathrm{O}}^{0}-\frac{j \times \delta_{a n} \times R \times T}{n_{e} F D_{\mathrm{H}_{2} \mathrm{O}}^{e f f}} \\
P_{\mathrm{O}_{2}}^{*} & =P_{\mathrm{O}_{2}}^{0}-\frac{j \times \delta_{\text {cat }} \times R \times T}{n_{e} F D_{\mathrm{O}_{2}}^{e f f}}
\end{aligned}
$$

in which, $P$ stands for the total pressure, and $D^{\text {eff }}{ }_{i}$ denotes the effective diffusion coefficient of the species $i$ at the cathode and anode. In porous media, diffusion is calculated via the Knudsen diffusion and the binary molecular diffusion [84]:

$$
D_{i}^{e f f}=\frac{\varepsilon}{\tau}\left(\frac{1}{D_{i, M}}+\frac{1}{D_{i, K}}\right)^{-1}
$$

where $D_{i, K}$ represents the Knudsen diffusion, $D_{i, M}$ stands for the diffusivity of species $i$ in the multi-component gas mixture, $t$ and $\varepsilon$ represent the tortuosity and porosity of the materials, correspondingly. Knudsen diffusion depends on cell temperature, the diameter of structure pore, and molecular weights of components [84]. Knudsen diffusion is determined by the following equation:

$$
D_{i, K}=4850 \times d_{\text {pore }} \sqrt{\frac{T}{M_{i}}}
$$

where $T$ represents the mean cell temperature, $d_{\text {pore }}$ stands for the structure pore diameter, and $M_{i}$ denotes the molecular weight of species $i$. The binary diffusion coefficient between species $j$ and $i$ in the free space is calculated via the Chapmane Enskog equation:

$$
D_{i j}=0.0018583 \frac{T^{\frac{3}{2}} \times M_{i j}^{0.5}}{P \times \tilde{\sigma}_{i j}^{2} \times \Omega_{D}}
$$

$M_{i j}$ denotes average molecular weight, $\Omega_{D}$ represents the collision diffusion integral based on the Lennarde Jones potential, and $\tilde{\sigma}$ stands for the collision diameter (Lennard Jones length):

$$
M_{i j}=\left(\frac{1}{M_{i}}+\frac{1}{M_{j}}\right)^{-1}
$$

Diffusivity of species $i$ in the multi-component gas mixture $D_{i, M}$ could be evaluated with Wilke's equation:

$$
D_{i, M}=\frac{1-x_{i}}{\sum_{j \neq i}^{n} \frac{x_{j}}{D_{i j}}}
$$

Finally, Equation (31) evaluates the electrical power that produced by a stack:

$$
\text { Power }_{\text {stack }}=N_{\text {cells }} \times A_{\text {cell }} \times j \times V
$$

Meanwhile, all required assumptions for evaluation of the cell voltage are presented in Table 1 , based on $[36,64,85]$. 
Table 1. SOFC simulation assumptions.

\begin{tabular}{|c|c|}
\hline Factor & Value \\
\hline \multicolumn{2}{|c|}{ Cathode [86] } \\
\hline Thickness $(\mu \mathrm{m})$ & 30 \\
\hline Average pore radius $(\mu \mathrm{m})$ & 0.5 \\
\hline Average particle diameter $(\mu \mathrm{m})$ & 2.5 \\
\hline Porosity & 0.48 \\
\hline Tortuosity & 5.4 \\
\hline Charge transfer coefficient & 0.5 \\
\hline \multicolumn{2}{|c|}{ Anode [86] } \\
\hline Thickness $(\mu \mathrm{m})$ & 750 \\
\hline Average pore radius $(\mu \mathrm{m})$ & 0.5 \\
\hline Average particle diameter $(\mu \mathrm{m})$ & 2.5 \\
\hline Specific area $\left(\mathrm{m}^{-1}\right)$ & $1.025 \times 10^{5}$ \\
\hline Porosity & 0.35 \\
\hline Tortuosity & 3.8 \\
\hline Charge transfer coefficient & 0.5 \\
\hline \multicolumn{2}{|c|}{ Electrolyte [86] } \\
\hline Thickness $(\mu \mathrm{m})$ & 25 \\
\hline Interconnect & \\
\hline Thickness $(\mu \mathrm{m})$ & 1500 \\
\hline \multicolumn{2}{|c|}{ Parameters for exchange current density [71] } \\
\hline Pre-exponential factor for cathode $\left(\mathrm{A} \cdot \mathrm{cm}^{-2}\right)$ & $6.5 \times 10^{7}$ \\
\hline Activation energy for cathode $\left(\mathrm{kj} \cdot \mathrm{mole}^{-1}\right)$ & 140 \\
\hline Pre-exponential factor for anode $\left(\mathrm{A} \cdot \mathrm{cm}^{-2}\right)$ & $2.35 \times 10^{7}$ \\
\hline Activation energy for anode $\left(\mathrm{kj} \cdot \mathrm{mole}^{-1}\right)$ & 137 \\
\hline \multicolumn{2}{|l|}{ Conductivity parameter $\left(\Omega^{-1} \cdot \mathrm{cm}^{-1}\right)[43]$} \\
\hline Anode & $\left(95 \times 10^{4} / \mathrm{T}\right) \exp (-1150 / \mathrm{T})$ \\
\hline Cathode & $\left(42 \times 10^{4} / \mathrm{T}\right) \exp (-1200 / \mathrm{T})$ \\
\hline Electrolyte & $334 \exp (-10,300 / \mathrm{T})$ \\
\hline Interconnect & $\left(9.3 \times 10^{4} / \mathrm{T}\right) \exp (-1100 / \mathrm{T})$ \\
\hline
\end{tabular}

\subsection{Energy Analysis}

The thermodynamic efficiency of the power cycle is defined as the ratio of net output power to the input heat absorbed by the working fluid. The mass and energy balances of any control volume at steady state with negligible kinetic and potential energy alterations are written as follows:

$$
\begin{gathered}
\sum \dot{m}_{i}=\sum \dot{m}_{e} \\
\dot{Q}-\dot{W}=\sum \dot{m}_{e} H_{e}-\sum \dot{m}_{i} H_{i}
\end{gathered}
$$

Based on the above equations, energy balance equation for the SOFC defined as [81]:

$$
\Sigma \dot{m}_{i n} H_{\text {in }}+\dot{m}_{f u e l} Q_{f u e l, L H V}=\Sigma \dot{m}_{\text {Out }} H_{\text {Out }}+W_{\text {SOFC }}
$$

The first law efficiency for a power generation cycle is as follows:

$$
\eta=\frac{W_{\text {net }}}{Q_{\text {input }}}
$$




\subsection{Exergy Analysis}

Exergy analysis is applied to the integrated power system to determine irreversibilities at the various operating stages. The dead state (reference point) for all exergy evaluations is adjusted to $T_{\text {dead-state }}=298.15 \mathrm{~K}$ and $P_{\text {dead-state }}=101.3 \mathrm{kPa}$.

The exergy is defined as the quality of various types of energy in relation to a given system. The exergy analysis is a relatively new method based on the concepts of both the first and second laws of thermodynamics. An exergy analysis applied to a process can indicate how much of the usable work potential, or exergy, introduced as the input to the process is destructed.

The concept of the theorem employed is based on the approach described in [87]. Exergy of a system can be divided into four parts including chemical, physical, potential and kinetic [88]. Since the kinetic and potential exergies are insignificance, these types are neglected [88]. As a consequence, the total exergy of the streams can be determined by Equation (36) in which the total exergy rate $\left(\dot{E x_{t o t}}\right)$ is calculated by summation of the chemical exergy rate $\left(\dot{E x_{c h}}\right)$.

$$
\dot{E} x_{t o t}=\dot{E} x_{p h}+\dot{E} x_{c h}
$$

In which the physical exergy rate can be determined by Equation (37) [89].

$$
\dot{E} x_{p h}=\left(\dot{H}_{T, P}-\dot{H}_{T_{0}, P_{0}}\right)-T_{0}\left(\dot{S}_{T, P}-\dot{S}_{T_{0}, P_{0}}\right)
$$

where, $\dot{S}_{T, P}$ and $\dot{H}_{T, P}$, denote the entropy and enthalpy rates of the streams at working pressure and temperature $(P, T)$, correspondingly, while $\dot{S}_{T_{0}, P_{0}}$ and $\dot{H}_{T_{0}, P_{0}}$ represent the entropy and enthalpy rates at the ambient temperature and pressure $(P=1 \mathrm{~atm}, T=298.15 \mathrm{~K})$, respectively. In Equation (35), chemical exergy rate of the mixture can be determined by Equation (38) [85] in which $x_{i}$ and $\dot{E}_{i}{ }^{0}$, represent mole fraction of component $i$, and standard chemical exergy, correspondingly:

$$
\dot{E} x_{c h}=\sum x_{i} \dot{E}_{i}^{0}+\dot{G}-\sum x_{i} \dot{G}_{i}
$$

Exergy balance for any control volume at the steady state condition with negligible kinetic and potential exergy alterations is as follows [87]:

$$
\dot{E} \dot{x}_{\text {heat }}-\dot{W}=E \dot{x}_{\text {tot }, \text { in }}-E x_{\text {tot }, \text { out }}+\dot{I}
$$

where $\dot{I}$ stands for exergy destruction rate and $\dot{E} x_{\text {heat }}$ shows the net exergy transfers by heat at temperature $T$ which can be obtained by [87]:

$$
\dot{E} x_{\text {heat }}=\left(1-\frac{T_{0}}{T}\right) \dot{Q}
$$

The exergy efficiency of a unit or plant can be calculated by the ratio of produced exergy to input exergy. Nevertheless, rational exergy, as an exergy-based efficiency, can be applied to have much more logical analysis for a plant due to high accuracy in determining input exergy to a plant. The rational exergy can be determined as [87]:

$$
\text { Rational efficiency }=\frac{\text { Actual exergy output }}{\text { Actual exergy input }}
$$

In Equation (40), the term actual exergy input represents the net exergy that the plant has access to it or is available for it. In another word, the plant has the equipment to benefit from these values of exergy. Summary of the relationships and the definitions that are used to calculate the exergy destruction and exergy efficiency of the principal components is shown in Table 2. 
Table 2. Summary of the relationships and the definitions used to calculate the exergy efficiency.

\begin{tabular}{|c|c|c|}
\hline Components & Exergy Destruction & Exergy Efficiency \\
\hline Compressors & $I=E x_{\mathrm{i}}-E x_{0}=\sum(\dot{m} \cdot e)_{i}+W-\sum(\dot{m} \cdot e)_{0}$ & $\varepsilon=\frac{\sum(\dot{m} .)_{i}-\sum(\dot{m} .)_{0}}{W}$ \\
\hline expanders & $I=E x_{\mathrm{i}}-E x_{0}=\sum(\dot{m} \cdot e)_{i}-\mathrm{W}-\sum(\dot{m} \cdot e)_{0}$ & $\varepsilon=\frac{W}{\sum(\dot{m} .)_{i}-\sum(\dot{m} .)_{0}}$ \\
\hline heat exchangers & $I=E x_{1}-E x_{0}=\sum(\dot{m} \cdot e)_{i}-\sum(\dot{m} \cdot e)_{0}$ & $\varepsilon=1-\left[\left\{\frac{\sum(\dot{m} \cdot \Delta e)}{\sum(\dot{m} \cdot \Delta h)}\right\}_{\mathrm{h}}-\left\{\frac{\sum(\dot{m} \cdot \Delta e)}{\sum(\dot{m} \cdot \Delta h)}\right\}_{c}\right]$ \\
\hline pumps & $I=E x_{\mathrm{i}}-E x_{0}=\sum(\dot{m} \cdot e)_{i}+W-\sum(\dot{m} \cdot e)_{0}$ & $\varepsilon=\frac{\sum(\dot{m} \cdot e)_{i}-\sum(\dot{m} \cdot e)_{0}}{W}$ \\
\hline separators, drums and reformers & $I=E x_{\mathrm{i}}-E x_{0}=\sum(\dot{m} \cdot e)_{i}-\sum(\dot{m} \cdot e)_{0}$ & $\varepsilon=\frac{\sum(\dot{m} . e)_{0}}{\sum(\dot{m} . e)_{i}}$ \\
\hline SOFC & $I=E x_{\mathrm{i}}-E x_{0}=\sum(\dot{m} \cdot e)_{i}-\sum(\dot{m} \cdot e)_{0}$ & $\varepsilon=\frac{W}{\sum(\dot{m} \cdot e)_{i}-\sum(\dot{m} \cdot e)_{0}}$ \\
\hline Cycle/process & Summation of irreversibility of all devices & $\varepsilon=1-\frac{\text { Total irreversibillity of cycle }}{\text { Total exergy input to cycle }}$ \\
\hline
\end{tabular}

\section{Process Simulation and Assumption}

In this work, the Aspen-HYSYS commercial software is utilized to simulate the processes. Comprehensive thermodynamic databases of the Aspen-HYSYS software provide chemical and physical properties of heterogeneous mixtures at variegated operating pressures and temperatures with a single fluid package. This chemical process simulator makes the simulation of the complex processes with lots of streams possible. Anderson et al. [90] performed a simulation of the SOFC reactor by Aspen-HYSYS. The intrinsic features of the Aspen-HYSYS without any linked codes formed their model of the simulation. They showed that the results of their model are reasonable over a wide range of conditions. Mehrpooya et al. [58] performed a study on a combined system containing SOFC, gas turbine, ammonia-water absorption refrigeration system and Rankine steam cycle. The SOFC part of their system was simulated by Aspen-HYSYS, and they showed that the electrochemical approach could estimate the experimental data with high precision. The assumptions for the simulation are shown in Table 3 [74].

Table 3. Assumptions of the simulation for the integrated power system.

\begin{tabular}{lc}
\hline \multicolumn{1}{c}{ Parameter } & Value \\
\hline Ambient temperature $\left({ }^{\circ} \mathrm{C}\right)$ & $20(293.15 \mathrm{~K})$ \\
Ambient pressure $($ bar $)$ & 1.013 \\
DC-AC inverter efficiency & $90 \%$ \\
Pre-Reformer conversion & $15 \%$ \\
Conversion in Combustor & $100 \%$ \\
Minimum steam-to-carbon ratio & 2.5 \\
Fuel cell temperature $\left({ }^{\circ} \mathrm{C}\right)$ & $814(1087 \mathrm{~K})$ \\
SOFC operating pressure $($ bar $)$ & 8.890 \\
Fuel utilization & 0.85 \\
Active surface area $\left(\mathrm{cm}^{2}\right)$ & 220 \\
Number of cell & 50,000 \\
Exchange current density of anode $\left(\mathrm{A} / \mathrm{cm}^{2}\right)$ & 0.6 \\
Exchange current density of cathode $\left(\mathrm{A} / \mathrm{cm}^{2}\right)$ & 0.22 \\
Inlet temperature to the Pre-reforming $\left({ }^{\circ} \mathrm{C}\right)$ & $427(700 \mathrm{~K})$ \\
Inlet temperature to the SOFC $\left({ }^{\circ} \mathrm{C}\right)$ & $427(700 \mathrm{~K})$ \\
Thickness of the anode $(\mathrm{cm})$ & 0.01 \\
Thickness of the cathode $(\mathrm{cm})$ & 0.22 \\
Thickness of the interconnect $(\mathrm{cm})$ & 0.0085 \\
Thickness of the electrolyte $(\mathrm{cm})$ & 0.004 \\
Pressure ratio of the LNG pump & 6 \\
Pump efficiency & $75 \%$ \\
ORC turbine efficiency & $80 \%$ \\
Gas turbine efficiency & $75 \%$ \\
Fuel compressor efficiency & $82 \%$ \\
Air compressor efficiency & $82 \%$ \\
\hline &
\end{tabular}


These assumptions include the SOFC model input data and the efficiency of the rotary instruments of the proposed system. These assumptions are taken based on a study that is carried out by Yan et al. [74].

The composition of the liquid natural gas stream which is utilized in the process is shown in Table 4, which is assumed based on operating LNG plant products. Soave-Redlich-Kwong (SRK) [91] and Peng-Robinson (PR) [86] equation of states are appropriate for the determination of thermodynamic properties of the operating conditions and the composition of the streams in the SOFC system. Therefore, the Peng-Robinson (PR) equation of states employed as a proper fluid package for the calculation of the thermodynamic properties.

Table 4. Composition of the liquid natural gas stream of the process.

\begin{tabular}{cc}
\hline Components & Mole Fraction \\
\hline Methane & 0.9800 \\
Ethane & 0.014 \\
Propane & 0.0040 \\
n-Butane & 0.0010 \\
Nitrogen & 0.0010 \\
\hline
\end{tabular}

\section{Results and Discussion}

\subsection{Exergy Analysis}

In this section, the results of the simulation are shown and the exergy and energy analyses of the system are carried out.

Table 5 represents the thermodynamic properties of the integrated power system such as pressure, molar flow rate of each stream, and temperature. Table 6 indicates the performance of the integrated power system. Additionally, the chemical, physical and total exergy of each stream is represented in Table 5. As Table 6 shows, the calculated energy efficiency of the organic Rankine cycle (21.93\%) is low compared to the modern power plants and it shows that a great deal of energy is dissipated by the considered cycle. However, efficiencies founded on energy can be vague and ambiguous, since it does not consider the quality of the energy. In fact, losses can enjoy a high amount of energy while in terms of thermodynamic, they are not significance and appreciable owing to their low quality. Nevertheless, efficiencies based on exergy can determine the quality of energy and measure of the deviation from ideality. According to Figure 2, showing the T-S diagram of the organic Rankine cycle, it could be considered that this cycle operates at low temperatures. The exergy analysis' results reveal that the exergy efficiency associated with the organic Rankine cycle is $64.92 \%$, which is high enough due to its low operating temperatures and low quality of the energy at these low temperatures.

Again, the exergy efficiency of the whole plant is measured to be $39.91 \%$ while the rational efficiency of the integrated power system is $53.46 \%$. The reason for such a difference lies in a significant amount of exergy loss rate at the regasification unit due to the lack of appropriate equipment to benefit from this exergy. The rational efficiency indicates that over half of the available exergy inputs to the plant is transferred to the power and a proportion of the irreversibilities are inevitable owing to the physical, technological, and economic constraints. Figure 3 depicts diverse input and output parameters in the integrated power system.

Again, the exergy efficiency of the whole plant is measured to be $39.91 \%$ while the rational efficiency of the integrated power system is $53.46 \%$. The reason for such a difference lies in a significant amount of exergy loss rate at regasification unit due to the lack of appropriate equipment to benefit from these amounts of exergy. 
Table 5. Operating conditions for the process depicted in Figure 1.

\begin{tabular}{|c|c|c|c|c|c|c|}
\hline Stream No. & $\begin{array}{c}\text { Temperature } \\
\text { (K) }\end{array}$ & $\begin{array}{l}\text { Pressure } \\
(\mathrm{kPa})\end{array}$ & $\begin{array}{c}\text { Flow } \\
(\mathrm{kmol} / \mathrm{h})\end{array}$ & $\begin{array}{c}\text { Physical } \\
\text { Exergy (kW) }\end{array}$ & $\begin{array}{c}\text { Chemical } \\
\text { Exergy }(\mathbf{k W})\end{array}$ & $\begin{array}{c}\text { Total Exergy } \\
(\mathbf{k W})\end{array}$ \\
\hline 1 & 293.15 & 101.3 & 388.8 & 4.199 & 12.24 & 12.24 \\
\hline 2 & 525.0 & 606.0 & 388.8 & 688.4 & 12.24 & 700.6 \\
\hline 3 & 299.6 & 586.0 & 388.8 & 469.1 & 12.24 & 481.4 \\
\hline 4 & 348.1 & 909.0 & 388.8 & 595.7 & 12.24 & 607.9 \\
\hline 5 & 700.0 & 889.0 & 388.8 & 1071 & 12.24 & 1083 \\
\hline $5(a)$ & 1119 & 889.0 & 339.8 & 1789 & 21.74 & 1811 \\
\hline 6 & 1119 & 889.0 & 522.9 & 1199 & 1661 & 2860 \\
\hline 7 & 1352 & 889.0 & 489.6 & 3683 & 532.1 & 4215 \\
\hline 8 & 1022 & 151.0 & 489.6 & 1855 & 532.1 & 2387 \\
\hline 9 & 765.3 & 141.0 & 489.6 & 1032 & 532.1 & 1564 \\
\hline 10 & 735.8 & 128.0 & 489.6 & 946.4 & 532.1 & 1479 \\
\hline 11 & 479.2 & 118.0 & 489.6 & 337.2 & 532.1 & 869.3 \\
\hline 12 & 347.5 & 104.3 & 489.6 & 143 & 532.1 & 675.6 \\
\hline 13 & 293.1 & 101.0 & 72.00 & 0.0616 & 234.2 & 234.2 \\
\hline 14 & 293.2 & 909.0 & 72.00 & 0.4033 & 234.2 & 234.6 \\
\hline 15 & 700.0 & 899.0 & 72.00 & 381.4 & 234.2 & 615.5 \\
\hline 16 & 113.1 & 121.0 & 1027 & 4880 & 243,057 & 247,937 \\
\hline 17 & 113.4 & 726.0 & 1027 & 4881 & 243,057 & 247,938 \\
\hline 18 & 140.7 & 726.0 & 1027 & 4281 & 243,057 & 247,342 \\
\hline 19 & 278.1 & 676.0 & 1027 & 1340 & 243,057 & 244,397 \\
\hline 20 & 345.9 & 606.0 & 1027 & 1301 & 243,057 & 244,358 \\
\hline 21 & 346.0 & 606.0 & 28.80 & 36.49 & 6692 & 6729 \\
\hline 22 & 346.0 & 606.0 & 998.2 & 1265 & 236,048 & 237,313 \\
\hline 23 & 384.5 & 909.0 & 28.80 & 46.84 & 6692 & 6739 \\
\hline 24 & 700.0 & 899.0 & 28.80 & 109.6 & 6692 & 6802 \\
\hline 25 & 633.5 & 899.0 & 107.6 & 334.1 & 7005 & 7339 \\
\hline 26 & 700.0 & 889.0 & 107.6 & 374.3 & 7005 & 7379 \\
\hline 27 & 260.0 & 20.00 & 489.6 & 4.255 & - & 4.255 \\
\hline 28 & 260.8 & 1500 & 44.26 & 5.848 & - & 5.848 \\
\hline 29 & 450.0 & 1500 & 44.26 & 114.9 & - & 114.9 \\
\hline 30 & 345.1 & 20.00 & 44.26 & -40.80 & - & -40.80 \\
\hline
\end{tabular}

Table 6. Results of energy and exergy analyses of the integrated power system simulation.

\begin{tabular}{lc}
\hline \multicolumn{1}{c}{ Parameter } & Value \\
\hline SOFC operating temperature $\left({ }^{\circ} \mathrm{C}\right)$ & 845.9 \\
After-burner combustion temperature $\left({ }^{\circ} \mathrm{C}\right)$ & 1057 \\
ORC turbine inlet temperature $\left({ }^{\circ} \mathrm{C}\right)$ & 176.9 \\
SOFC operating current density $\left(\mathrm{A} / \mathrm{m}^{2}\right)$ & 4628 \\
Cell operating voltage $(\mathrm{V})$ & 0.575 \\
SOFC electrical power $(\mathrm{kW})$ & 2928 \\
Air Compressor 1 power $(\mathrm{kW})$ & 759.5 \\
Air Compressor 2 power $(\mathrm{kW})$ & 153.1 \\
Fuel compressor power $(\mathrm{kW})$ & 11.89 \\
ORC-Pump & 2.383 \\
LNG-Pump & 8.807 \\
Water-Pump & 0.3839 \\
Gas turbine power & 1682 \\
ORC turbine power & 127.3 \\
Energy efficiency of ORC $(\%)$ & 21.93 \\
Exergy efficiency of ORC $(\%)$ & 64.92 \\
Overall exergy efficiency of plant $(\%)$ & 39.91 \\
Rational efficiency of plant $(\%)$ & 53.46 \\
\hline
\end{tabular}




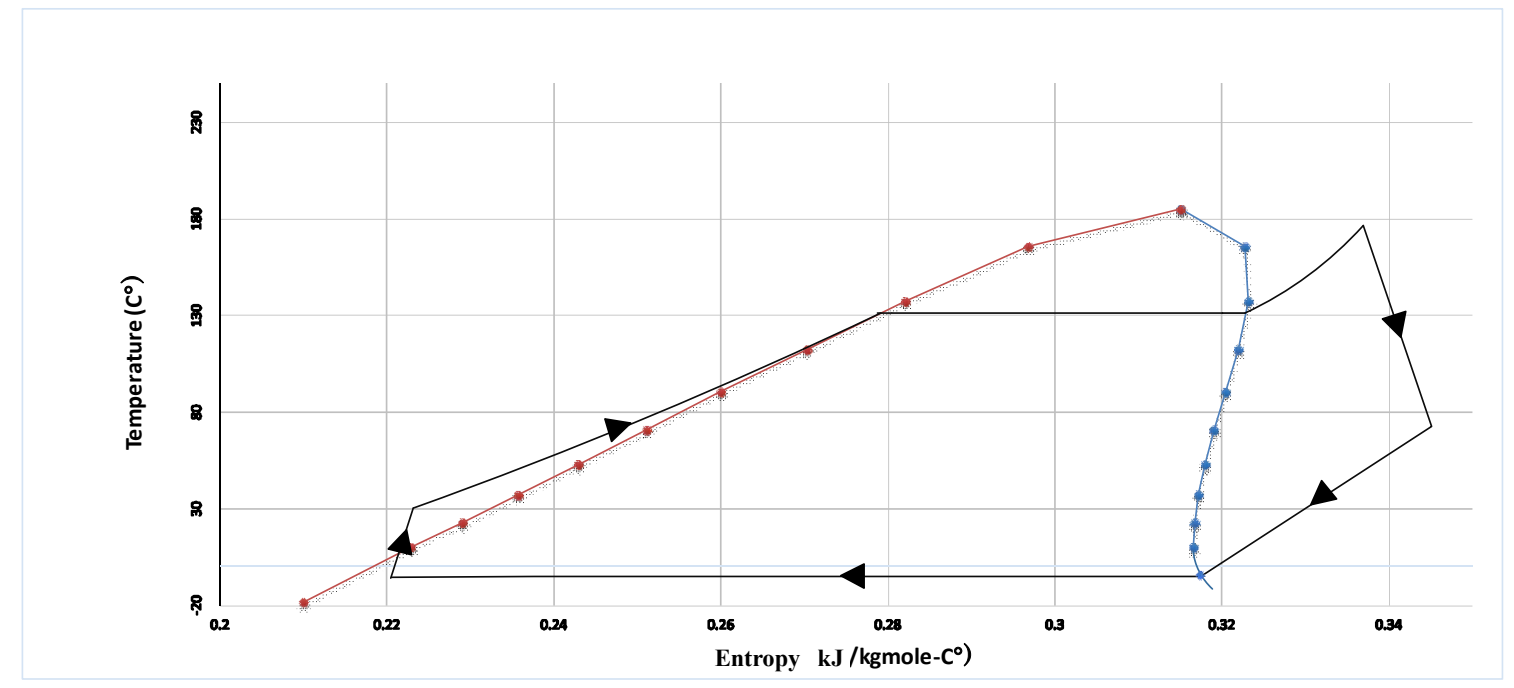

Figure 2. T-S diagram of the organic Rankine cycle.

The rational efficiency indicates that over half of the available exergy inputs to the plant is transferred to the power and a proportion of the irreversibilities are inevitable owing to the physical, technological, and economic constraints. Figure 3 depicts diverse input and output parameters in the integrated power system.

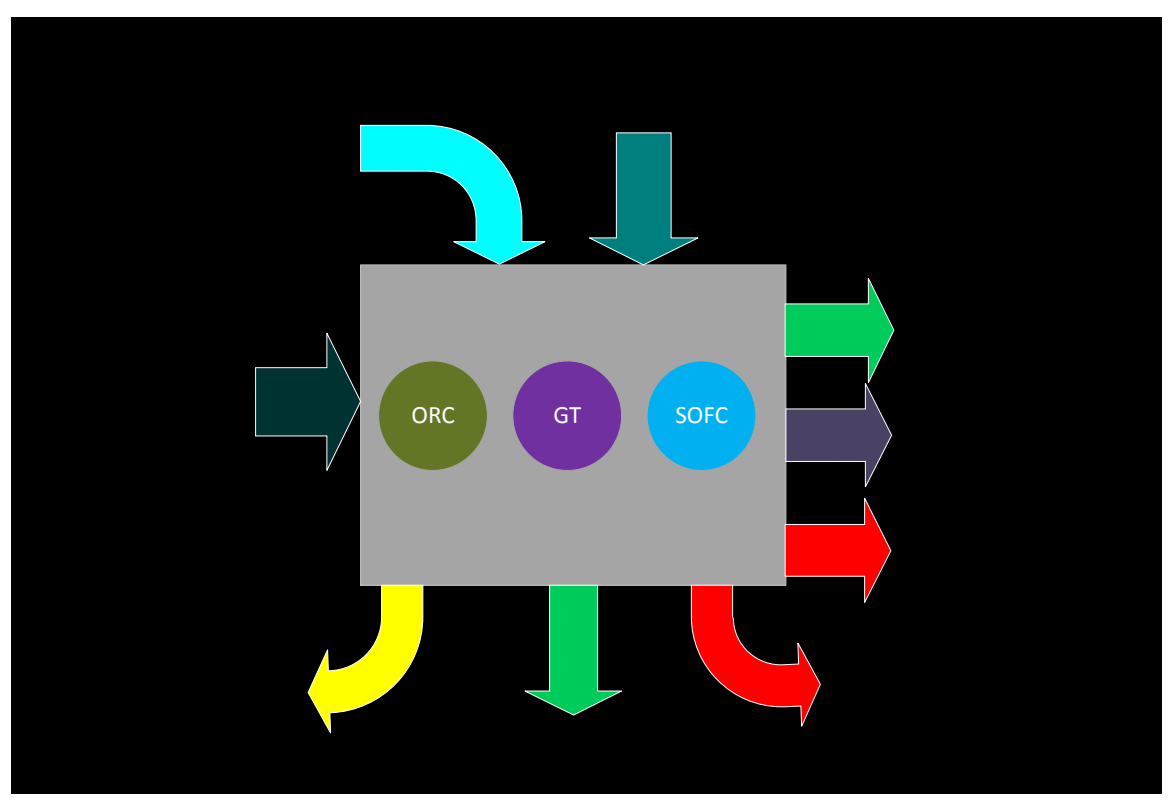

Figure 3. Various exergy input and output factors in the integrated power system.

Furthermore, the exergy efficiency and exergy destruction of the influential components of the process are listed in Table 7. Regarding Table 7, the lowest exergy efficiency among components belongs to LNG pump due to the low temperature of the LNG stream and rough operating climate of this component. Furthermore, the exergy destruction rate of the afterburner is dominant over all other irreversibilities. This high exergy destruction rate indicates that appreciable opportunities for improvements exist in the afterburner rather than other equipment. In addition, the majority of the exergy efficiencies of the multi-stream heat exchangers are lower than $80 \%$ which show that the performance of the heat exchangers is far from lagging behind the ideality. 
Table 7. Results of exergy destruction and exergy efficiency.

\begin{tabular}{ccc}
\hline Components & Exergy Destruction $\mathbf{( k W )}$ & Exergy Efficiency (\%) \\
\hline Air-compressor 1 & 90.09 & 88.43 \\
Air-compressor 2 & 26.28 & 82.83 \\
Methane-compressor & 2.253 & 81.63 \\
Water-pump & 0.0599 & 83.36 \\
ORC-pump & 0.7361 & 51.47 \\
LNG-pump & 7.814 & 11.73 \\
Gas-turbine & 174.1 & 89.48 \\
ORC-turbine & 28.42 & 77.69 \\
HX-1 & 258.2 & 66.82 \\
HX-2 & 218.9 & 76.94 \\
HX-3 & 51.02 & 62.37 \\
HX-4 & 228.8 & 80.35 \\
HX-5 & 550.9 & 61.62 \\
HX-6 & 84.65 & 85.05 \\
Pre-Reforming & 78.5 & 98.95 \\
SOFC reactor & 931 & 75.68 \\
Inverter & 260.4 & 91.83 \\
After burner & 456 & 90.23 \\
\hline
\end{tabular}

According to Table 7, the heat exchanger (HX-5) that operates with LNG low-temperature stream, has the lowest exergy efficiency among other heat exchangers. The reason for this phenomenon is that, at lower temperatures with a constant rate of heat transfer, entropy generation has a higher value [92]. Figure 4 shows the various types of exergy destruction in the integrated power system as a Grassmann diagram. According to Figure 4 and Table 7, the SOFC reactor is ranked third in exergy destruction rate among other units despite its acceptable exergy efficiency compared to other equipment.

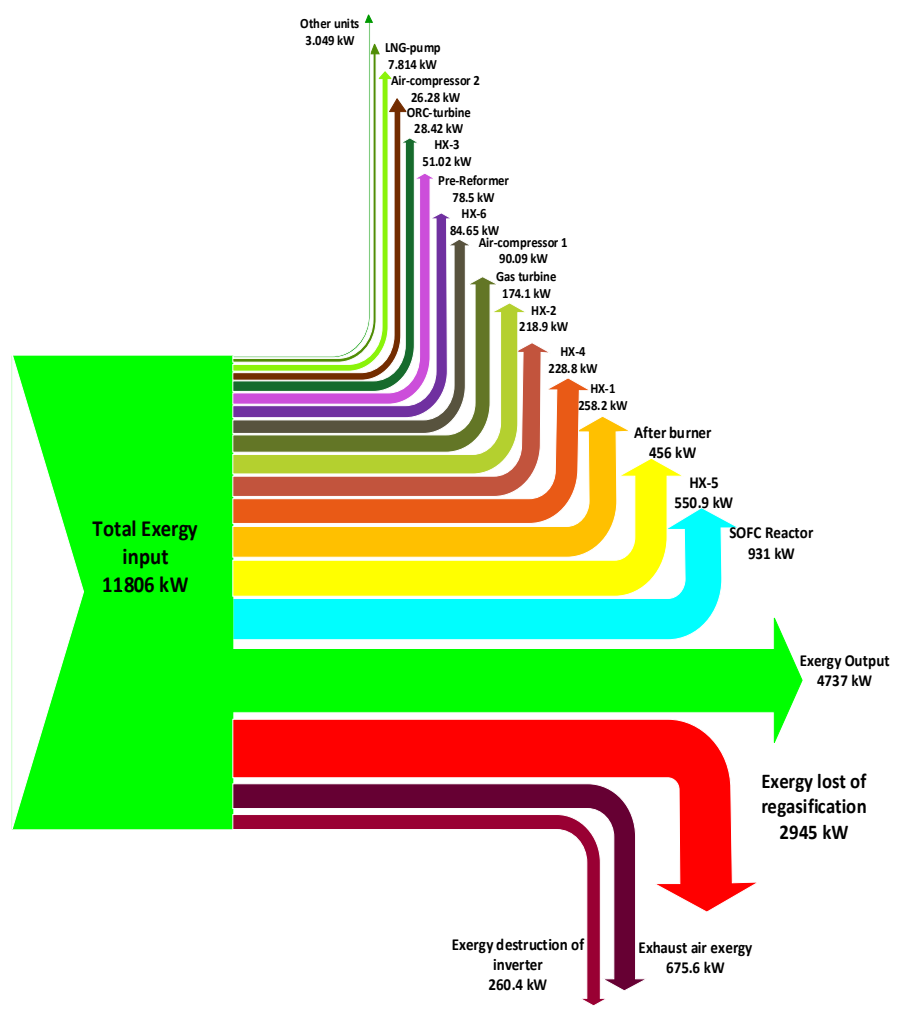

Figure 4. Exergy flow diagram depicting the exergy destruction in the integrated power plant. 


\subsection{Composite Curves}

A number of authors have described and applied composite curves to the heat exchangers of power plants. Klemes [93] and Bandyopadhyay [94] carried out studies about the importance of the composite curves in waste reduction in the heat exchangers. The composite curves (T-H diagrams) indicate the variation of the temperature in terms of the enthalpy contribution. In other words, by drawing the rates of enthalpy cumulatively against corresponding temperatures, one curve for the hot streams and one curve for the cold streams can be obtained. In these curves, the cooled curve (the hot composite curve) is always above the heated curve (the cold composite curve). By overlapping the interval between the composite curves, the corresponding heat exchanger can operate more efficiently. This overlapping can be achieved by moving the curves closer together horizontally. Economically, minimum approach temperature is equal to the point where the vertical distance between the curves has the smallest value while in terms of the thermodynamics, minimum approach temperature is the point where this distance becomes zero.

The heat exchangers' composite curves associated with the plant are depicted in Figure 5. Regarding Figure 5, at the heat exchanger (HX-1), the min approach temperature is near to $21.4{ }^{\circ} \mathrm{C}$, and it is located just after the cold inlet side of the heat exchanger. The cold and hot pinch temperatures are $26.4{ }^{\circ} \mathrm{C}$ and $5{ }^{\circ} \mathrm{C}$, respectively. On the other hand, the minimum approach temperature of the heat exchanger (HX-2) is near to $321.8^{\circ} \mathrm{C}$, which is located at the cold end of the heat exchanger.

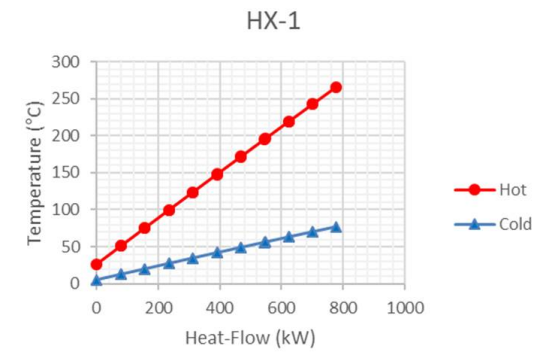

(a)

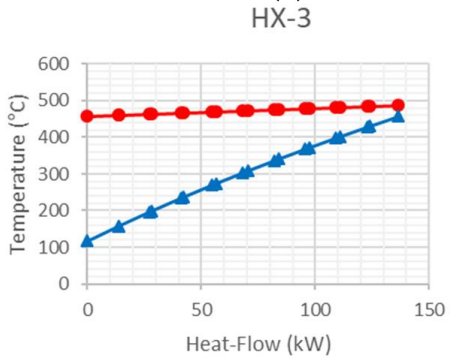

(c)

HX-5

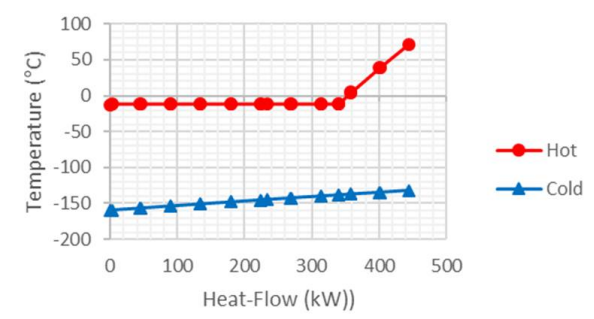

(e)

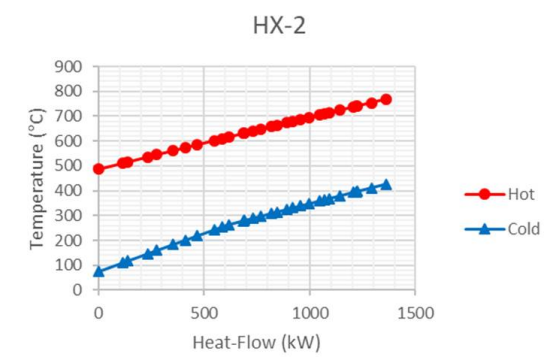

(b)

HX-4

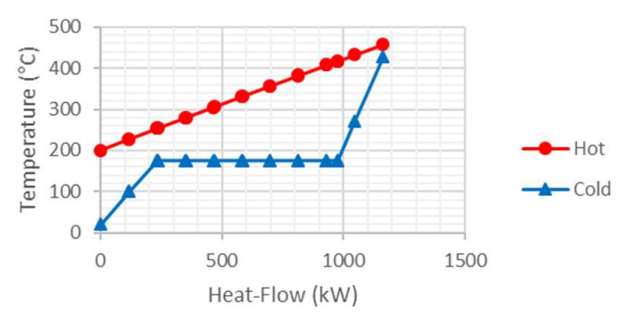

(d)

HX-6

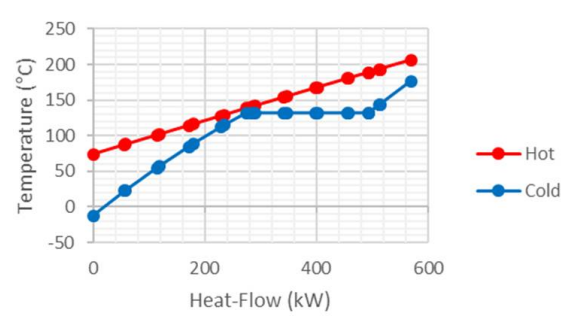

(f)

Figure 5. Hot (red) and cold (blue) composite curves for the heat exchangers.

As mentioned above, a high minimum approach temperature indicates that there is a great potential for optimizing the heat exchanger performance. However, economic limitations and sizing issues force one to choose a high minimum approach temperature. The cold composite curve of the 
heat exchanger (HX-4) shows that the curve appears horizontal at temperature $175{ }^{\circ} \mathrm{C}$, due to the phase changing of the stream. The minimum approach temperature of this heat exchanger is located at the cold end of it and its value is approximately $36^{\circ} \mathrm{C}$. According to Figure 5, at the heat exchanger (HX-5), the min approach temperature is located just after the working fluid of the ORC cycle starts to condense. Due to the cryogenic temperatures of the LNG stream, the value of the minimum approach temperature is estimated as high as $127.5^{\circ} \mathrm{C}$.

\section{Conclusions}

An integrated power generation system including the SOFC reactor, gas turbine, and organic Rankine cycle with LNG as a heat sink is simulated by the Aspen-HYSYS simulator, followed by energy and exergy analyses based on the results of the simulation. As the result of the energy analysis shown, the energy efficiency of the organic Rankine cycle (21.93\%) is lower than other modern power plants despite its high exergy efficiency $(64.92 \%)$. This fact shows the weakness of the energy efficiency in the determination of the quality of energy at low temperatures and significance of the efficient performance of organic Rankine cycle at these low temperatures. In addition, the exergy analysis illustrates that the exergy and rational efficiencies of the whole plant measured to be $39.91 \%$ and $53.46 \%$, respectively. The most significant results of the exergy analysis are as follows:

(a) The exergy losses and difference between the rational and exergy efficiencies can be enumerated as the circumstances of low efficiencies of equipment in regasification unit.

(b) The highest values of exergy destruction rate associate with the afterburner and heat exchanger (HX-5), which are equal to 456 and $550.9 \mathrm{~kW}$, respectively, indicating that appreciable potential for improvements exists in these units. The lowest value for exergy destruction belongs to water-pump which is equal to $0.0599 \mathrm{~kW}$.

(c) It is worth to note that the high exergy destruction rate of the heat exchanger (HX-5) is due partially to the cryogenic temperature of the LNG stream, causing more entropy generation.

(d) The lowest exergy efficiency among components belongs to the LNG pump which is equal to $11.73 \%$, owning to the rough operating climates of this unit.

(e) Due to the low exergy efficiency of the majority of the heat exchangers, there is a lack of heat recovery in the heat exchangers. The composite curves of the heat exchangers show that the minimum approach temperatures of some heat exchangers (HX-2 and HX-5) have high values, revealing that there is a great potential for optimizing the heat exchanger performance.

(f) Economical and technical restrictions and sizing matters dictate some exergy destruction rates to the heat exchangers and the whole plants, known as unavoidable irreversibilities.

(g) An exergy flow diagram is represented in order to get better insight into exergy destruction in different components of the system.

Author Contributions: The work is conducted and wrote by M.H.A., M.S.S. and M.G. under the supervision of F.P., O.M., M.M. and S.W.

Acknowledgments: Somchai Wongwises acknowledges financial support provided by the "Research Chair Grant" National Science and Technology Development Agency (NSTDA), the Thailand Research Fund (TRF), and King Mongkut's University of Technology Thonburi through the "KMUTT 55th Anniversary Commemorative Fund".

Conflicts of Interest: The authors declare no conflict of interest.

\section{References}

1. Amin, T.E.; Roghayeh, G.; Fatemeh, R.; Fatollah, P. Evaluation of Nanoparticle Shape Effect on a Nanofluid Based Flat-Plate Solar Collector Efficiency. Energy Explor. Exploit. 2015, 33, 659-676. [CrossRef]

2. Noorollahi, Y.; Gholami Arjenaki, H.; Ghasempour, R. Thermo-economic modeling and GIS-based spatial data analysis of ground source heat pump systems for regional shallow geothermal mapping. Renew. Sustain. Energy Rev. 2017, 72, 648-660. [CrossRef] 
3. Narei, H.; Ghasempour, R.; Noorollahi, Y. The effect of employing nanofluid on reducing the bore length of a vertical ground-source heat pump. Energy Convers. Manag. 2016, 123, 581-591. [CrossRef]

4. Lorentzen, G.; Pettersen, J. A new, efficient and environmentally benign system for car air-conditioning. Int. J. Refrig. 1993, 16, 4-12. [CrossRef]

5. Kim, M.-H.; Pettersen, J.; Bullard, C.W. Fundamental process and system design issues in $\mathrm{CO}_{2}$ vapor compression systems. Prog. Energy Combust. Sci. 2004, 30, 119-174. [CrossRef]

6. Riffat, S.B.; Zhao, X. A novel hybrid heat pipe solar collector/CHP system-Part 1: System design and construction. Renew. Energy 2004, 29, 2217-2233. [CrossRef]

7. Riffat, S.B.; Zhao, X. A novel hybrid heat-pipe solar collector/CHP system-Part II: Theoretical and experimental investigations. Renew. Energy 2004, 29, 1965-1990. [CrossRef]

8. Jokar, M.A.; Ahmadi, M.H.; Sharifpur, M.; Meyer, J.P.; Pourfayaz, F.; Ming, T. Thermodynamic evaluation and multi-objective optimization of molten carbonate fuel cell-supercritical $\mathrm{CO}_{2}$ Brayton cycle hybrid system. Energy Convers. Manag. 2017, 153, 538-556. [CrossRef]

9. Chen, Y.; Lundqvist, P.; Johansson, A.; Platell, P. A comparative study of the carbon dioxide transcritical power cycle compared with an organic rankine cycle with R123 as working fluid in waste heat recovery. Appl. Therm. Eng. 2006, 26, 2142-2147. [CrossRef]

10. Yang, J.L.; Ma, Y.T.; Li, M.X.; Guan, H.Q. Exergy analysis of transcritical carbon dioxide refrigeration cycle with an expander. Energy 2005, 30, 1162-1175. [CrossRef]

11. Cayer, E.; Galanis, N.; Desilets, M.; Nesreddine, H.; Roy, P. Analysis of a carbon dioxide transcritical power cycle using a low temperature source. Appl. Energy 2009, 86, 1055-1063. [CrossRef]

12. Kumar, S.; Kwon, H.-T.; Choi, K.-H.; Lim, W.; Cho, J.H.; Tak, K.; Moon, I. LNG: An eco-friendly cryogenic fuel for sustainable development. Appl. Energy 2011, 88, 4264-4273. [CrossRef]

13. Ahmadi, M.H.; Mehrpooya, M.; Abbasi, S.; Pourfayaz, F.; Bruno, J.C. Thermo-economic analysis and multi-objective optimization of a transcritical $\mathrm{CO}_{2}$ power cycle driven by solar energy and LNG cold recovery. Therm. Sci. Eng. Prog. 2017, 4, 185-196. [CrossRef]

14. Romero Gómez, M.; Ferreiro Garcia, R.; Romero Gómez, J.; Carbia Carril, J. Review of thermal cycles exploiting the exergy of liquefied natural gas in the regasification process. Renew. Sustain. Energy Rev. 2014, 38, 781-795. [CrossRef]

15. Sun, Z.; Wang, J.; Dai, Y.; Wang, J. Exergy analysis and optimization of a hydrogen production process by a solar-liquefied natural gas hybrid driven transcritical $\mathrm{CO}_{2}$ power cycle. Int. J. Hydrog. Energy 2012, 37, 18731-18739. [CrossRef]

16. Wang, J.; Yan, Z.; Wang, M.; Dai, Y. Thermodynamic analysis and optimization of an ammonia-water power system with LNG (liquefied natural gas) as its heat sink. Energy 2013, 50, 513-522. [CrossRef]

17. Kim, C.W.; Chang, S.D.; Ro, S.T. Analysis of the power cycle utilizing the cold energy of LNG. Int. J. Energy Res. 1995, 19, 741-749. [CrossRef]

18. Zhang, N.; Lior, N. A novel near-zero $\mathrm{CO}_{2}$ emission thermal cycle with LNG cryogenic exergy utilization. Energy 2006, 31, 1666-1679. [CrossRef]

19. Kanagawa, T. Japan's LNG Utilization and Environmental Efforts; The Japan Gas Association: Tokyo, Japan, 2008.

20. Dispenza, C.; Dispenza, G.; La Rocca, V.; Panno, G. Exergy recovery during LNG regasification: Electric energy production-Part one. Appl. Therm. Eng. 2009, 29, 380-387. [CrossRef]

21. Dispenza, C.; Dispenza, G.; La Rocca, V.; Panno, G. Exergy recovery during LNG regasification: Electric energy production-Part two. Appl. Therm. Eng. 2009, 29, 388-399. [CrossRef]

22. Szargut, J.; Szczygiel, I. Utilization of the cryogenic exergy of liquid natural gas (LNG) for the production of electricity. Energy 2009, 34, 827-837. [CrossRef]

23. Choi, I.-H.; Lee, S.; Seo, Y.; Chang, D. Analysis and optimization of cascade Rankine cycle for liquefied natural gas cold energy recovery. Energy 2013, 61, 179-195. [CrossRef]

24. Gómez, M.R.; Garcia, R.F.; Gómez, J.R.; Carril, J.C. Thermodynamic analysis of a Brayton cycle and Rankine cycle arranged in series exploiting the cold exergy of LNG (liquefied natural gas). Energy 2014, 66, 927-937. [CrossRef]

25. Dong, H.; Zhao, L.; Zhang, S.; Wang, A.; Cai, J. Using cryogenic exergy of liquefied natural gas for electricity production with the Stirling cycle. Energy 2013, 63, 10-18. [CrossRef]

26. Rao, W.-J.; Zhao, L.-J.; Liu, C.; Zhang, M.-G. A combined cycle utilizing LNG and low-temperature solar energy. Appl. Therm. Eng. 2013, 60, 51-60. [CrossRef] 
27. Song, Y.; Wang, J.; Dai, Y.; Zhou, E. Thermodynamic analysis of a transcritical $\mathrm{CO}_{2}$ power cycle driven by solar energy with liquified natural gas as its heat sink. Appl. Energy 2012, 92, 194-203. [CrossRef]

28. Xia, G.; Sun, Q.; Cao, X.; Wang, J.; Yu, Y.; Wang, L. Thermodynamic analysis and optimization of a solar-powered transcritical $\mathrm{CO}_{2}$ (carbon dioxide) power cycle for reverse osmosis desalination based on the recovery of cryogenic energy of LNG (liquefied natural gas). Energy 2014, 66, 643-653. [CrossRef]

29. Liu, M.; Lior, N.; Zhang, N.; Han, W. Thermoeconomic analysis of a novel zero- $\mathrm{CO}_{2}$-emission high-efficiency power cycle using LNG coldness. Energy Convers. Manag. 2009, 50, 2768-2781. [CrossRef]

30. Zhang, N.; Lior, N.; Liu, M.; Han, W. COOLCEP (cool clean efficient power): A novel $\mathrm{CO}_{2}$-capturing oxy-fuel power system with LNG (liquefied natural gas) coldness energy utilization. Energy 2010, 35, 1200-1210. [CrossRef]

31. Alabdulkarem, A.; Hwang, Y.; Radermacher, R. Energy consumption reduction in $\mathrm{CO}_{2}$ capturing and sequestration of an LNG plant through process integration and waste heat utilization. Int. J. Greenh. Gas Control 2012, 10, 215-228. [CrossRef]

32. Beigzadeh, M.; Pourfayaz, F.; Ahmadi, M.H.; Pourkiaei, S.M.; Beigzadeh, M. A Simplificative Approach-based Modeling of SOFC Power Systems Fed by Natural Gas. Fuel Cells 2017, 17, 843-853. [CrossRef]

33. Zhang, X.; Chan, S.H.; Li, G.; Ho, H.K.; Li, J.; Feng, Z. A review of integration strategies for solid oxide fuel cells. J. Power Sources 2010, 195, 685-702. [CrossRef]

34. Chan, S.H.; Ho, H.K.; Tian, Y. Modelling of simple hybrid solid oxide fuel cell and gas turbine power plant. J. Power Sources 2002, 109, 111-120. [CrossRef]

35. Calise, F.; Palombo, A.; Vanoli, L. Design and partial load exergy analysis of hybrid SOFC-GT power plant. J. Power Sources 2006, 158, 225-244. [CrossRef]

36. Zhang, X.; Li, J.; Li, G.; Feng, Z. Cycle analysis of an integrated solid oxide fuel cell and recuperative gas turbine with an air reheating system. J. Power Sources 2007, 164, 752-760. [CrossRef]

37. Burbank, W.; Witmer, D.D.; Holcomb, F. Model of a novel pressurized solid oxide fuel cell gas turbine hybrid engine. J. Power Sources 2009, 193, 656-664. [CrossRef]

38. Haseli, Y.; Dincer, I.; Naterer, G.F. Thermodynamic modeling of a gas turbine cycle combined with a solid oxide fuel cell. Int. J. Hydrog. Energy 2008, 33, 5811-5822. [CrossRef]

39. Bao, C.; Shi, Y.; Li, C.; Cai, N.; Su, Q. Multi-level simulation platform of SOFC-GT hybrid generation system. Int. J. Hydrog. Energy 2010, 35, 2894-2899. [CrossRef]

40. Bao, C.; Cai, N.; Croiset, E. A multi-level simulation platform of natural gas internal reforming solid oxide fuel cell-gas turbine hybrid generation system-Part II. Balancing units model library and system simulation. J. Power Sources 2011, 196, 8424-8434. [CrossRef]

41. Zaccaria, V.; Tucker, D.; Traverso, A. Transfer function development for SOFC/GT hybrid systems control using cold air bypass. Appl. Energy 2016, 165, 695-706. [CrossRef]

42. Camblong, H.; Baudoin, S.; Vechiu, I.; Etxeberria, A. Design of a SOFC/GT/SCs hybrid power system to supply a rural isolated microgrid. Energy Convers. Manag. 2016, 117, 12-20. [CrossRef]

43. Wu, W.; Chen, S.-A.; Chiu, Y.-C. Design and Control of an SOFC/GT Hybrid Power Generation System with Low Carbon Emissions. Ind. Eng. Chem. Res. 2016, 55, 1281-1291. [CrossRef]

44. Lv, X.; Liu, X.; Gu, C.; Weng, Y. Determination of safe operation zone for an intermediate-temperature solid oxide fuel cell and gas turbine hybrid system. Energy 2016, 99, 91-102. [CrossRef]

45. Saebea, D.; Authayanun, S.; Patcharavorachot, Y.; Arpornwichanop, A. Effect of anode-cathode exhaust gas recirculation on energy recuperation in a solid oxide fuel cell-gas turbine hybrid power system. Energy 2016, 94, 218-232. [CrossRef]

46. Sanaye, S.; Katebi, A. 4E analysis and multi objective optimization of a micro gas turbine and solid oxide fuel cell hybrid combined heat and power system. J. Power Sources 2014, 247, 294-306. [CrossRef]

47. Lee, Y.D.; Ahn, K.Y.; Morosuk, T.; Tsatsaronis, G. Exergetic and exergoeconomic evaluation of a solid-oxide fuel-cell-based combined heat and power generation system. Energy Convers. Manag. 2014, 85, 154-164. [CrossRef]

48. Barelli, L.; Bidini, G.; Ottaviano, A. Part load operation of SOFC/GT hybrid systems: Stationary analysis. Int. J. Hydrog. Energy 2012, 37, 16140-16150. [CrossRef]

49. Gandiglio, M.; Lanzini, A.; Leone, P.; Santarelli, M.; Borchiellini, R. Thermoeconomic analysis of large solid oxide fuel cell plants: Atmospheric vs. pressurized performance. Energy 2013, 55, 142-155. [CrossRef] 
50. Pierobon, L.; Rokni, M. Thermodynamic Analysis of an Integrated Gasification Solid Oxide Fuel Cell Plant with a Kalina Cycle. Int. J. Green Energy 2015, 12, 610-619. [CrossRef]

51. Rokni, M. Thermodynamic analyses of municipal solid waste gasification plant integrated with solid oxide fuel cell and Stirling hybrid system. Int. J. Hydrog. Energy 2015, 40, 7855-7869. [CrossRef]

52. Jradi, M.; Riffat, S. Tri-generation systems: Energy policies, prime movers, cooling technologies, configurations and operation strategies. Renew. Sustain. Energy Rev. 2014, 32, 396-415. [CrossRef]

53. Sadeghi, S.; Ameri, M. Exergy Analysis of Photovoltaic Panels-Coupled Solid Oxide Fuel Cell and Gas Turbine-Electrolyzer Hybrid System. J. Energy Resour. Technol. 2014, 136, 31201. [CrossRef]

54. Choudhury, A.; Chandra, H.; Arora, A. Application of solid oxide fuel cell technology for power generation-A review. Renew. Sustain. Energy Rev. 2013, 20, 430-442. [CrossRef]

55. Buonomano, A.; Calise, F.; d'Accadia, M.D.; Palombo, A.; Vicidomini, M. Hybrid solid oxide fuel cells-gas turbine systems for combined heat and power: A review. Appl. Energy 2015, 156, 32-85. [CrossRef]

56. Rokni, M. Thermodynamic analysis of an integrated solid oxide fuel cell cycle with a rankine cycle. Energy Convers. Manag. 2010, 51, 2724-2732. [CrossRef]

57. Rokni, M. Plant characteristics of an integrated solid oxide fuel cell cycle and a steam cycle. Energy 2010, 35, 4691-4699. [CrossRef]

58. Mehrpooya, M.; Dehghani, H.; Ali Moosavian, S.M. Optimal design of solid oxide fuel cell, ammonia-water single effect absorption cycle and Rankine steam cycle hybrid system. J. Power Sources 2016, 306, 107-123. [CrossRef]

59. Verda, V. Solid Oxide Fuel Cell System Configurations for Distributed Generation. J. Fuel Cell Sci. Technol. 2008, 5, 41001. [CrossRef]

60. Ghirardo, F.; Santin, M.; Traverso, A.; Massardo, A. Heat recovery options for onboard fuel cell systems. Int. J. Hydrog. Energy 2011, 36, 8134-8142. [CrossRef]

61. Al-Sulaiman, F.A.; Hamdullahpur, F.; Dincer, I. Performance comparison of three trigeneration systems using organic rankine cycles. Energy 2011, 36, 5741-5754. [CrossRef]

62. Pierobon, L.; Rokni, M.; Larsen, U.; Haglind, F. Thermodynamic analysis of an integrated gasification solid oxide fuel cell plant combined with an organic Rankine cycle. Renew. Energy 2013, 60, 226-234. [CrossRef]

63. Ozcan, H.; Dincer, I. Thermodynamic Analysis of an Integrated SOFC, Solar ORC and Absorption Chiller for Tri-generation Applications. Fuel Cells 2013, 13. [CrossRef]

64. Ozcan, H. Performance evaluation of an SOFC based trigeneration system using various gaseous fuels from biomass gasification. Int. J. Hydrog. Energy 2015, 40, 7798-7807. [CrossRef]

65. Bao, J.; Zhao, L. A review of working fluid and expander selections for organic Rankine cycle. Renew. Sustain. Energy Rev. 2013, 24, 325-342. [CrossRef]

66. Akkaya, A.V.; Sahin, B. A study on performance of solid oxide fuel cell-organic Rankine cycle combined system. Int. J. Energy Res. 2009, 33, 553-564. [CrossRef]

67. Al-Sulaiman, F.A.; Hamdullahpur, F. Energy analysis of a trigeneration plant based on solid oxide fuel cell and organic Rankine cycle. Int. J. Hydrog. Energy 2010, 35, 5104-5113. [CrossRef]

68. Tsatsaronis, G.; Morosuk, T. Advanced exergetic analysis of a novel system for generating electricity and vaporizing liquefied natural gas. Energy 2010, 35, 820-829. [CrossRef]

69. Kim, T.; Ro, S. Power augmentation of combined cycle power plants using cold energy of liquefied natural gas. Energy 2000, 25, 841-856. [CrossRef]

70. Angelino, G.; Invernizzi, C.M. Carbon dioxide power cycles using liquid natural gas as heat sink. Appl. Therm. Eng. 2009, 29, 2935-2941. [CrossRef]

71. Liu, Y.; Guo, K. A novel cryogenic power cycle for LNG cold energy recovery. Energy 2011, 36, $2828-2833$. [CrossRef]

72. Eveloy, V.; Karunkeyoon, W.; Rodgers, P.; Al Alili, A. Energy, exergy and economic analysis of an integrated solid oxide fuel cell-Gas turbine-Organic Rankine power generation system. Int. J. Hydrog. Energy 2016, 41, 13843-13858. [CrossRef]

73. Ebrahimi, M.; Moradpoor, I. Combined solid oxide fuel cell, micro-gas turbine and organic Rankine cycle for power generation (SOFC-MGT-ORC). Energy Convers. Manag. 2016, 116, 120-133. [CrossRef]

74. Yan, Z.; Zhao, P.; Wang, J.; Dai, Y. Thermodynamic analysis of an SOFC-GT-ORC integrated power system with liquefied natural gas as heat sink. Int. J. Hydrog. Energy 2013, 38, 3352-3363. [CrossRef] 
75. Shekhawat, D.; Spivey, J.J.; Berry, D.A. Fuel Cells: Technologies for Fuel Processing; Elsevier: Amsterdam, The Netherlands, 2011.

76. Braun, R.J. Optimal Design and Operation of Solid Oxide Fuel Cell Systems for Small-Scale Stationary Applications; University of Wisconsin: Madison, WI, USA, 2002.

77. Spiegel, C. Designing and Building Fuel Cells; McGraw-Hill: New York, NY, USA, 2007.

78. Bove, R.; Ubertini, S. (Eds.) Modeling Solid Oxide Fuel Cells: Methods, Procedures and Techniques; Springer Science: Berlin, Germany, 2008.

79. Hou, K.; Hughes, R. The kinetics of methane steam reforming over a Ni $/ \alpha-\mathrm{Al}_{2} \mathrm{O}$ catalyst. Chem. Eng. J. 2001, 82, 311-328. [CrossRef]

80. Perry, R.H.; Green, D.W. Perry's Chemical Engineers' Handbook; McGraw-Hill: New York, NY, USA, 2008.

81. Meng, Q.; Han, J.; Kong, L.; Liu, H.; Zhang, T.; Yu, Z. Thermodynamic analysis of combined power generation system based on SOFC/GT and transcritical carbon dioxide cycle. Int. J. Hydrog. Energy 2017, 42, 4673-4678. [CrossRef]

82. Hosseinpour, J.; Sadeghi, M.; Chitsaz, A.; Ranjbar, F.; Rosen, M.A. Exergy assessment and optimization of a cogeneration system based on a solid oxide fuel cell integrated with a Stirling engine. Energy Convers. Manag. 2017, 143, 448-458. [CrossRef]

83. Choudhary, T. Sanjay. Thermodynamic assessment of SOFC-ICGT hybrid cycle: Energy analysis and entropy generation minimization. Energy 2017, 134, 1013-1028. [CrossRef]

84. Sghaier, S.F.; Khir, T.; Ben Brahim, A. Energetic and exergetic parametric study of a SOFC-GT hybrid power plant. Int. J. Hydrog. Energy 2018, 43, 3542-3554. [CrossRef]

85. Janardhanan, V.M.; Heuveline, V.; Deutschmann, O. Performance analysis of a SOFC under direct internal reforming conditions. J. Power Sources 2007, 172, 296-307. [CrossRef]

86. Peng, D.-Y.; Robinson, D.B. A New Two-Constant Equation of State. Ind. Eng. Chem. Fundam. 1976, 15, 59-64. [CrossRef]

87. Kotas, T.J. The Exergy Method of Thermal Plant Analysis; Elsevier: Amsterdam, The Netherlands, 2013.

88. Shamoushaki, M.; Ehyaei, M.A.; Ghanatir, F. Exergy, economic and environmental analysis and multi-objective optimization of a SOFC-GT power plant. Energy 2017, 134, 515-531. [CrossRef]

89. Mehrpooya, M.; Jarrahian, A.; Pishvaie, M.R. Simulation and exergy-method analysis of an industrial refrigeration cycle used in NGL recovery units. Int. J. Energy Res. 2006, 30, 1336-1351. [CrossRef]

90. Anderson, T.; Vijay, P.; Tade, M.O. An adaptable steady state Aspen Hysys model for the methane fuelled solid oxide fuel cell. Chem. Eng. Res. Des. 2014, 92, 295-307. [CrossRef]

91. 90 Soave, G. Equilibrium constants from a modified Redlich-Kwong equation of state. Chem. Eng. Sci. 1972, 27, 1197-1203. [CrossRef]

92. Mehrpooya, M.; Hossieni, M.; Vatani, A. Novel LNG-Based Integrated Process Configuration Alternatives for Coproduction of LNG and NGL. Ind. Eng. Chem. Res. 2014, 53, 17705-17721. [CrossRef]

93. Klemeš, J.J. (Ed.) Handbook of Process Integration (PI): Minimisation of Energy and Water Use, Waste and Emissions; Elsevier: Amsterdam, The Netherlands, 2013.

94. Bandyopadhyay, S. Source composite curve for waste reduction. Chem. Eng. J. 2006, 125, 99-110. [CrossRef]

(C) 2018 by the authors. Licensee MDPI, Basel, Switzerland. This article is an open access article distributed under the terms and conditions of the Creative Commons Attribution (CC BY) license (http://creativecommons.org/licenses/by/4.0/). 